\title{
Pengenalan Pola Reflektansi Spektral Di Teluk Benoa Sebagai Indikator Perubahan Kerapatan Mangrove Berbasis Citra Landsat 8
}

\author{
Introduction of Spectral Reflectance Pattern in Benoa Bay as an \\ Indicator of Density Change of Mangrove Based on Landsat 8 \\ Image
}

\author{
Wiwik Kurniawati $^{1 *}$, I Made Yuliara ${ }^{1}$, Ni Nyoman Ratini ${ }^{1}$, Windarjoto ${ }^{1}$ \\ ${ }^{1}$ Program Studi Fisika, Fakultas Matematika dan Ilmu Pengetahuan Alam, Universitas Udayana, \\ Kampus Bukit, Jimbaran, Badung, Bali, Indonesia 80361 \\ Email: *wiwikkurniawati@sudent.unud.ac.id; imdyuliara@unud.ac.id; nymratini@unud.ac.id;
} windaryoto@unud.ac.id

\begin{abstract}
Abstrak - Telah dilakukan studi mengenai pengenalan pola reflektansi spektral sebagai indikator perubahan distribusi kerapatan mangrove menggunakan data time series citra Landsat 8, di daerah kawasan Teluk Benoa, Bali. Tujuan penelitian ini adalah untuk mengetahui distribusi kerapatan dan luas areal mangrove dari pola reflektansi spektralnya. Metode dan analisis menggunakan reflektansi spektral dan indeks vegetasi Normalized Difference Vegetation Index (NDVI). Hasil penentuan nilai reflektansi spectral menunjukkan bahwa, perubahan pola reflektansi spektral mangrove di Teluk Benoa dari tahun 2017-2020 mengalami penurunan dan kenaikan untuk setiap band-nya. Pola reflektansi band 5 dapat digunakan sebagai acuan terhadap pengurangan luasan areal mangrove, dimana semakin kecil nilai reflektansi pada band 5 dari tahun 2017-2020 menunjukkan pengurangan atau perubahan kerapatan mangrove di tahun tersebut semakin besar. Berdasarkan data sebaran citra indeks vegetasi NDVI pada tahun 2017-2020 diperoleh tutupan luas per kategori dimana terdapat pengurangan luas areal mangrove dari tahun 2017 hingga 2018 sebesar 36,72 ha, akan tetapi pada tahun 2019 luasan areal mangrove mengalami peningkatan yang cukup besar dari tahun 2018 yaitu sebesar 60,82 ha. Pada tahun 2020 luasan areal mangrove kembali mengalami pengurangan yang cukup drastis yaitu sebesar 181,51 ha. Luasan areal yang tercatat masih ditumbuhi mangrove pada tahun 2020 yaitu hanya sebesar 852,39 ha.
\end{abstract}

Kata kunci: Citra Landsat 8, mangrove Teluk Benoa, NDVI, pola reflektansi spektral, vegetasi

\begin{abstract}
Studies have been conducted on the introduction of spectral reflectance patterns as an indicator of changes in mangrove density distribution using landsat 8 imagery time series data, in benoa bay area, Bali. Methods and analyses use spectral reflectance and the Vegetation Normalized Difference Vegetation Index (NDVI). The results of determining the value of spectral reflectance show that, changes in mangrove spectral reflectance patterns in Benoa Bay from 2017-2020 have decreased and increased for each band. In the pattern of reflectance band 5 can be used as a reference there has been a reduction in mangrove area, where the smaller the value of reflectants in band 5 in 2017-2020 shows a reduction or change in mangrove density in the year is getting larger. Based on the data of NDVI vegetation index image distribution in 2017-2020 obtained wide cover per category that there is a reduction in mangrove area from 2017 to 2018 of 36.72 ha, but in 2019 mangrove area increased considerably from 2018 of $60.82 \mathrm{ha}$. In 2020 the mangrove area again experienced a fairly drastic reduction of $181.51 \mathrm{ha}$. The area recorded is still overgrown with mangroves in 2020 only amounting to 852.39 ha.
\end{abstract}

Keywords: Image of Landsat 8, mangrove of Benoa Bay, NDVI, spectral reflectance pattern, vegetation

\section{Pendahuluan}

Hutan mangrove merupakan tempat hidup berbagai jenis ikan dan udang yang dapat menunjang hasil tangkapan ikan para nelayan dan petani tambak [1]. Salah satu kawasan hutan mangrove di Bali adalah Teluk Benoa. Hutan mangrove Teluk Benoa merupakan kawan hutan mangrove terluas di Bali yang membentang di wilayah Denpasar dan Badung. Ironisnya, pada tahun 2018 sejumlah proyek (reklamasi) 
terus mendegradasi kawasan Teluk Benoa yang mengakibatkan terjadinya kerusakan hutan mangrove di Teluk Benoa [2].

Pencegahan dan penanggulangan kerusakan hutan mangrove dapat dilakukan melalui inventarisasi mangrove. Inventariasi pengumpulan data di lapangan umumnya dilakukan dengan satuan contoh (sampling unit). Akan tetapi dalam proses pengumpulan datanya membutuhkan tenaga dan biaya yang besar. Untuk mengatasi hal ini, cara alternatif yang dapat digunakan yaitu dengan memanfaatkan teknologi satelit penginderaan jauh.

Pemanfaatan citra penginderaan jauh dalam pemantauan keadaan vegetasi dapat dianalisis dari nilai indeks vegetasi [3]. Indeks vegetasi dapat diekstrak dari data citra penginderaan jauh yang mana besarnya sangat bergantung pada kondisi vegetasi saat perekaman data citra dan secara kuantitas merupakan rasio dari reflektansi spektral (Trisakti, dkk., 2014). Vegetasi yang sehat, aktif melakukan fotosintesis dan kerapatan tinggi, memiliki nilai indeks vegetasi yang relatif besar pada reflektansi spektrum gelombang inframerah $(\lambda=0,8-1,4 \mathrm{~nm})[4]$.

Salah satu data penginderaan jauh yang dapat dimanfaatkan adalah citra satelit Landsat 8 . Data citra Landsat 8 dapat memberikan informasi mengenai karakteristik mangrove yang direpresentasikan oleh variasi nilai piksel-piksel yang terdapat pada citra. Adanya variasi nilai piksel, dimungkinkan untuk mengamati dan mendapatkan berbagai informasi termasuk karakteristik pantulan/reflektansi dari mangrove, sehingga bisa digunakam sebagai indikator perubahan kerapatan suatu vegetasi [5].

Berdasarkan uraian di atas, maka untuk melihat dan menganalisis secara cepat bila telah terjadi perubahan distribusi kerapatan dan luas areal mangrove berdasarkan pola reflektansi spektral sebagai indikator kerusakan mangrove pada tahun 2017-2020, perlu dilakukan suatu penelitian pemantauan mangrove di Teluk Benoa Bali secara times series.

\section{Landasan Teori}

\subsection{Pola reflektansi spektral}

Pola spektral (spectral signature) merupakan variasi reflektansi atau pantulan suatu objek sebagai reaksi akibat teradiasi oleh gelombang elektromagnetik dengan panjang gelombang tertentu [6]. Pola spektral terbentuk oleh perbedaan kemampuan berbagai material dalam menyerap, memantulkan dan memancarkan energi radiasi.

Respon reflektansi spektral objek di permukaan bumi dipengaruhi oleh beberapa faktor diantaranya sudut zenit matahari, sudut ketinggian, sudut azimut matahari, arah relatif sensor terhadap nadir dan kondisi objek. Hal ini dapat ditunjukkan dalam Gambar 1.

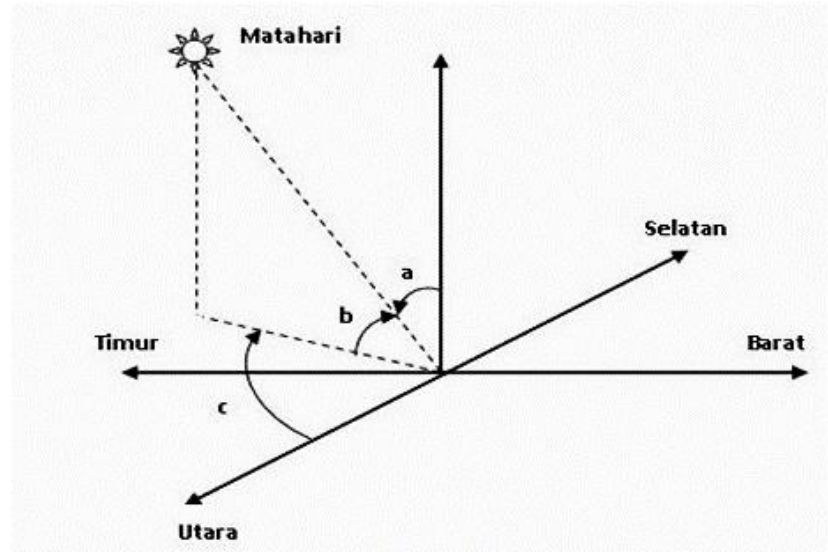

Gambar 1. Respon reflektansi spektral objek dipermukaan bumi (www.bing.com).

Karakteristik reflektansi spektral dari vegetasi dipengaruhi oleh kandungan pigmen daun, material organik, air dan karakteristik struktural daun seperti bentuk daun dan luas daun [7]. Nilai reflektansi spektral vegetasi pada band panjang gelombang tampak biru dan merah, memiliki nilai yang rendah hal ini disebabkan oleh serapan klorofil untuk fotosintesis. Vegetasi memiliki nilai reflektansi yang tinggi pada panjang gelombang hijau, dan hal ini sebagai penyebab vegetasi terlihat berwarna hijau. Pada 
Gambar 2 merupakan reflektansi spektral dari suatau vegetasi pada panjang gelombang tampak dan inframerah.

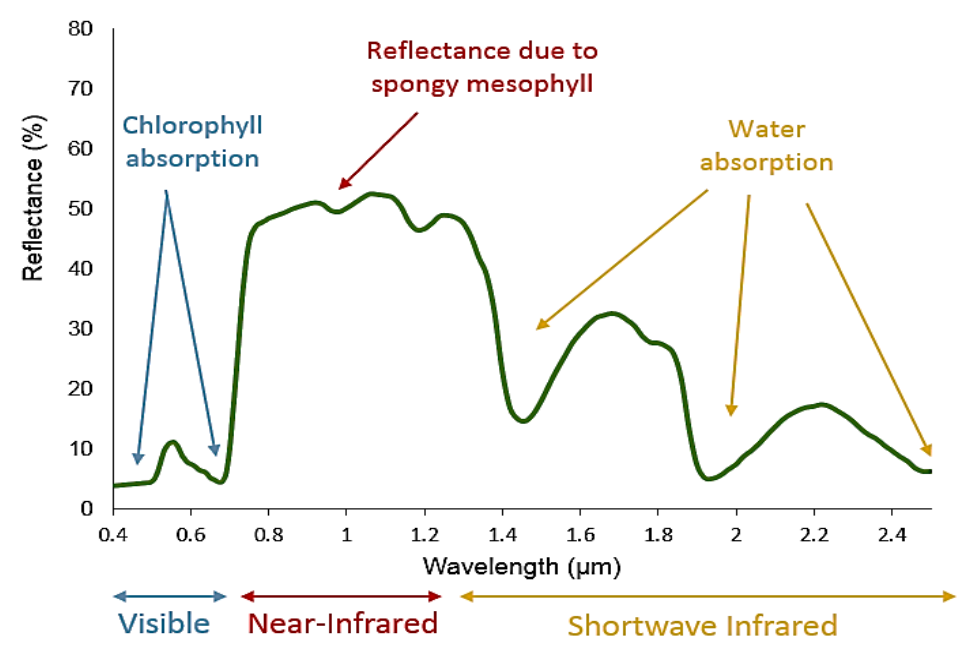

Gambar 2. Reflektansi spektral vegetasi (www.bing.com).

Reflektansi spektral pada Landsat 8 dapat ditentukan dengan mengkoreksi citra terhadap efek atmosfer melalui konversi nilai piksel-piksel citra mentah menjadi nilai reflektansi spectral $\left(\rho_{\lambda}\right)$ pada Top of Atmosphere (TOA) menggunakan Persamaan 1) [8], yaitu:

$$
\rho_{\lambda}=\frac{\rho_{\lambda}^{\prime}}{\cos \theta_{s z}}=\frac{M_{\rho} Q_{c a l}+A_{\rho}}{\sin \theta}
$$

Dimana $\rho_{\lambda}^{\prime}=$ nilai reflektansi spektral tanpa koreksi terhadap sudut matahari (\%), $\mathrm{M}_{\rho}=$ band specific multiplicative rescaling factor (REFLECTANCE_MULT_BAND_x, dimana $\mathrm{x}$ adalah band yang digunakan yang diperoleh dari meta data), $\mathrm{A}_{\rho}=$ band specific additive rescaling factor (REFLECTANCE_ADD_BAND_x, dimana $\mathrm{x}$ adalah band yang digunakan yang diperoleh dari meta data), $\mathrm{Q}_{\text {cal }}=$ Quantized dan calibrated standard product pixel values $(\mathrm{DN}), \theta_{S E}=$ Local sun elevation angle. The scene center sun elevation angle in degrees (SUN_ELEVATION), dan $\theta_{S Z}=$ Local solar zenith angle; $\theta_{S Z}=90^{\circ}-\theta_{S E}$.

\subsection{Hutan mangrove}

Hutan mangrove adalah komunitas tumbuhan yang tumbuh di daerah pasang surut. Hutan mangrove dikenal juga dengan istilah tidal forest, coastal woodland, vloedbosschen dan hutan payau. Hutan mangrove oleh masyarakat Indonesia dan negara Asia Tenggara lainnya yang berbahasa Melayu sering disebut dengan hutan bakau. Salah satu keunikan dari hutan mangrove adalah mempunyai sistem perakaran yang menonjol yang disebut dengan akar nafas (pneumatofor) yang digunakan untuk adaptasi terhadap keadaan tanah yang miskin oksigen.

Manfaat mangrove diantaranya sebagai penghasil bahan pelapukan yang merupakan sumber makanan penting bagi invertebrata kecil pemakan bahan pelapukan (detritus), yang berperan sebagai sumber makanan bagi hewan yang lebih besar, sebagai kawasan pemijah atau asuhan (nurse ground) bagi udang, ikan, kepiting, kerang yang setelah dewasa akan kembali ke lepas pantai. Juga penghasil kayu untuk bahan kontruksi, kayu bakar, bahan baku arang dan bahan baku kertas (pulp), pemasok larva ikan, udang, dan biota laut lainnnya, juga sebagai tempat pariwisata [9].

Indonesia memiliki tidak kurang dari 89 jenis tumbuhan mangrove atau paling tidak menurut FAO terdapat sebanyak 37 jenis. Dari berbagai jenis mangrove tersebut, yang hidup di daerah pasang surut, tahan air garam dan berbuah terdapat sekitar 12 famili. Dari sekian banyak jenis mangrove di Indonesia, jenis mangrove yang banyak ditemukan antara lain adalah jenis api-api (Avicennia sp.), bakau (Rhizophora sp.), tancang (Bruguiera sp.) dan bogem atau pedada (Sonneratia 5 sp.). Jenis-jenis mangrove tersebut adalah kelompok mangrove yang menangkap, menahan endapan dan menstabilkan tanah habitatnya. Jenis api-api (Avicennia sp.) atau yang dikenal sebagai black mangrove merupakan 
jenis terbaik dalam proses menstabilkan tanah habitatnya. Dikategorikan sebagai jenis terbaik, karena penyebaran benihnya mudah, toleransi terhadap temperatur tinggi, cepat menumbuhkan akar pernafasan (akar pasak) dan sistem perakaran di bawahnya mampu menahan endapan dengan baik. Mangrove besar, mangrove merah (Rhizophora sp.) merupakan jenis kedua terbaik. Jenis-jenis tersebut dapat mengurangi dampak kerusakan yang disebabkan oleh arus, gelombang besar maupun angin [10].

Pada umumnya, kerusakan mangrove terjadi karena dua hal yaitu, secara alamiah dan adanya aktivitas manusia. Kerusakan alamiah timbul karena peristiwa alam seperti adanya topan badai atau iklim kering berkepanjangan, sedangkan kerusakan karena aktivitas manusia seperti adanya kegiatan reklamasi, pemanfaatan atau penebangan kayu dan dijadikan sebagai tempat pembuangan sampah.

Mangrove di teluk Benoa merupakan Taman Wisata Alam Prapat Benoa yang ditetapkan sebagai Taman Hutan Raya (Tahura) Ngurah Rai berdasarkan Keputusan Menteri Kehutanan No. 544/KptsII/1993 tanggal 25 September 1993 dengan luas 1.373,50 Ha. Secara administrasi pemerintahan, mangrove teluk Benoa terletak di Kecamatan Kuta Kabupaten Badung dan Kecamatan Denpasar Selatan Kota Denpasar, Provinsi Bali. Mangrove di Teluk Benoa secara keseluruhan merupakan kawasan darat yang dipengaruhi oleh pasang surut air laut dan lereng menurun ke arah timur dengan ketinggian antara 0-3 $\mathrm{m}$ di atas permukaan laut.

\subsection{Kerapatan vegetasi dan indeks vegetasi}

Kerapatan vegetasi merupakan satu aspek yang mempengaruhi karakteristik vegetasi dalam citra. Kerapatan vegetasi umumnya diwujudkan dalam bentuk persentase dan untuk mengetahui tingkat suatu kerapatan vegetasi dapat dilihat dari korelasi indeks vegetasi terhadap reflektansi spektralnya melalui analisis digital. Pada data citra Landsat ditemukan korelasi positif sebesar 0,9 antara reflektansi spektral dengan kerapatan vegetasi. Kerapatan vegetasi direpresentasikan oleh suatu nilai indeks yang dapat diperoleh melalui transformasi indeks vegetasi pada citra (biasanya pada citra multiband). Hasil transformasi dapat menonjolkan aspek kerapatan vegetasi ataupun aspek lain yang berkaitan dengan kerapatan, misalnya biomassa, Leaf Area Index (LAI) maupun konsentrasi klorofil. Secara praktis, transformasi indeks vegetasi berupa transformasi matematis yang melibatkan beberapa band sekaligus, dan menghasilkan citra baru yang lebih representatif dalam menyajikan fenomena vegetasi [11]. Besarnya nilai indeks hasil transformasi juga menunjukkan besarnya nilai kehijauan vegetasi. Umumnya, untuk pemantauan vegetasi, transformasi dilakukan dengan perbandingan antara tingkat kecerahan band panjang gelombang merah dan infra merah dekat. Beberapa perumusan atau model transformasi indeks vegetasi yang dapat digunakan dalam pemantauan suatu vegetasi yaitu, Soil Adjusted Vegetation Index (SAVI), Enhanched Vegetation Index (EVI) dan Normalized Difference Vegetation Index (NDVI). Model indeks vegetasi yang paling umum digunakan adalah NDVI. Adapun formulasi NDVI adalah seperti ditunjukkan pada Persamaan (2) [12], yaitu:

$$
N D V I=\frac{\rho N I R-\rho \operatorname{Re} d}{\rho N I R+\rho \operatorname{Re} d}
$$

Dimana $\rho$ NIR = nilai reflektansi band infra merah dekat, dan $\rho$ Red $=$ nilai reflektansi band merah.

Rentang nilai yang digunakan dalam mengelompokkan tingkat kerapatan mangrove hasil perhitungan NDVI disajikan pada Tabel 1 [13].

Tabel 1. Kategori tingkat kerapatan berdasarkan nilai NDVI.

\begin{tabular}{ccc}
\hline No. & Rentang nilai NDVI & Kategori tingkat kerapatan \\
\hline 1 & $0,43 \leq \mathrm{NDVI} \leq 1,00$ & Rapat \\
2 & $0,33 \leq \mathrm{NDVI} \leq 0,42$ & Sedang \\
3 & $-1,0 \leq \mathrm{NDVI} \leq 0,32$ & Jarang \\
\hline
\end{tabular}

\subsection{Citra satelit Landsat 8}

Landsat 8 memiliki 2 sensor dengan 11 band, dimana 9 band terdapat pada sensor Onboard Operational Land Imager (OLI) dan 2 band lainnya terdapat pada sensor Thermal Infrared Sensor (TIRS). Pada Tabel 2 menunjukkan daftar 11 band yang terdapat pada citra satelit Landsat 8. 


\section{Metode Penelitian}

Penelitian ini menggunakan data citra Landsat 8 tahun 2017 sampai 2020 pada path/row 116/66 yang diunduh dari situs http://earthexplorer.usgs.gov/. Software yang digunakan adalah Idrisi Taiga 16.3. Obyek yang diteliti dalam penelitian ini adalah vegetasi hutan mangrove yang berada dikawasan Teluk

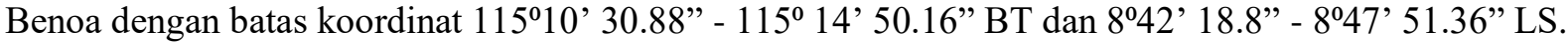

Tabel 2. Spesifikasi band pada citra Landsat 8 OLI.

\begin{tabular}{|c|c|c|c|}
\hline Band Spektral & $\begin{array}{c}\text { Panjang } \\
\text { Gelombang }(\mu)\end{array}$ & $\begin{array}{c}\text { Resolusi } \\
\text { Spasial (m) }\end{array}$ & Kegunaan dalam pemetaan \\
\hline Band 1 - Coastal Aerosol & $0,43-0,45$ & 30 & Penelitian Coastal dan Aerosol \\
\hline Band 2 - Blue & $0,45-0,51$ & 30 & $\begin{array}{l}\text { Membedakan tanah dari vegetasi dan daun dari } \\
\text { vegetasi konifer }\end{array}$ \\
\hline Band 3 - Green & $0,53-0,59$ & 30 & Memepertegas puncak vegetasi \\
\hline Band $4-$ Red & $0,64-0,67$ & 30 & Membedakan sudut vegetasi \\
\hline Band 5 - Near Infrared & $0,85-0,88$ & 30 & Menekankan konten biomassa dan garis pantai \\
\hline $\begin{array}{l}\text { Band } 6 \text { - Short Wavelength } \\
\text { InfraRed }\end{array}$ & $1,57-1,65$ & 30 & $\begin{array}{l}\text { Mendiskriminasikan kadar air tanah dengan } \\
\text { vegetasi }\end{array}$ \\
\hline $\begin{array}{l}\text { Band } 7 \text { - Short Wavelength } \\
\text { InfraRed }\end{array}$ & $2,11-2,29$ & 30 & $\begin{array}{l}\text { Peningkatan kadar air tanah dan vegetasi dan } \\
\text { penetrasi awan tipis }\end{array}$ \\
\hline Band 8 - Panchromatic & $0,50-0,68$ & 15 & Penajaman citra \\
\hline Band 9 - Cirrus & $1,36-1,38$ & 30 & $\begin{array}{l}\text { Peningkatan deteksi awan sirus yang } \\
\text { terkontaminasi }\end{array}$ \\
\hline $\begin{array}{l}\text { Band } 10 \text { - Long Wavelength } \\
\text { InfraRed }\end{array}$ & $10,60-11,19$ & 100 & $\begin{array}{l}\text { Pemetaan suhu dan penghitungan kelembaban } \\
\text { tanah }\end{array}$ \\
\hline $\begin{array}{l}\text { Bnad } 11 \text { - Long Wavelength } \\
\text { InfraRed }\end{array}$ & $11,50-12,51$ & 100 & $\begin{array}{l}\text { Peningkatan pemetaan suhu dan penghitungan } \\
\text { kelembaban tanah }\end{array}$ \\
\hline
\end{tabular}

Tahapan pengolahan data citra dan analisis pada penelitian ini secara garis besar dibagi dalam 3 tahap, yaitu: pra pengolahan, pengolahan dan analisis. Pada tahap pra pengolahan citra Landsat 8 di koreksi geometrik dengan tujuan agar posisi piksel pada citra memiliki koordinat yang sesuai dengan koordinat geografis. Setelah dikoreksi geometrik, citra kemudian dikonversi ke reflektansi spectral menggunakan Persamaan 1). Cropping citra dilakukan sesuai dengan batas koordinat daerah studi. Setelah melakukan pengolahan, dilanjutkan dengan tahapan processing yang terdiri dari beberapa tahapan yaitu, pembuatan citra komposit (RGB) yang disusun dari band 6,5 dan 4. Citra komposit ini digunakan sebagai dasar dalam melakukan klasifikasi citra. Klasifikasi citra mangrove-non mangrove di identifikasi menggunakan indeks vegetasi NDVI sesuai Persamaan 2). Penyesuaikan koordinat mangrove pada citra dilakukan dengan koordinat mangrove hasil pengukuran di lapangan menggunakan GPS. Tahapan terakhir dalam pengolahan data citra untuk mendapatkan tingkat kerapatan mangrove adalah dengan melakukan tabulasi silang yang bertujuan untuk menganalisis hubungan secara kuantitatif antara variabel citra indeks mangrove dengan citra klasifikasi mangrove-non mangrove. Dasar pengambilan keputusan menggunakan uji chi square dan indeks kappa. Analisis secara deskriptif dilakukan dengan memberikan argumentasi dan interpretasi terhadap citra time series hasil kerapatan mangrove yang dikaitkan dengan pola reflektansi spectral dari setiap series Landsat 8 yang digunakan pada penelitian. Proses pengolahan data penelitian Landsat 8 secara lengkap disajikan pada Gambar 3.

\section{Hasil Dan Pembahasan}

\subsection{Pola reflektansi spektral}

Dari hasil pengolahan data citra maka didapatkan pola reflektansi spektral untuk tahun 2017 sampai tahun 2020 seperti pada Gambar 4.

Perubahan interval rata-rata reflektansi spektral untuk setiap band (band 2 sampai band 7) untuk setiap tahunnya ditampilkan dalam grafik seperti pada Gambar 5. 
Introduction of Spectral Reflectance Pattern in Benoa Bay as an Indicator ........

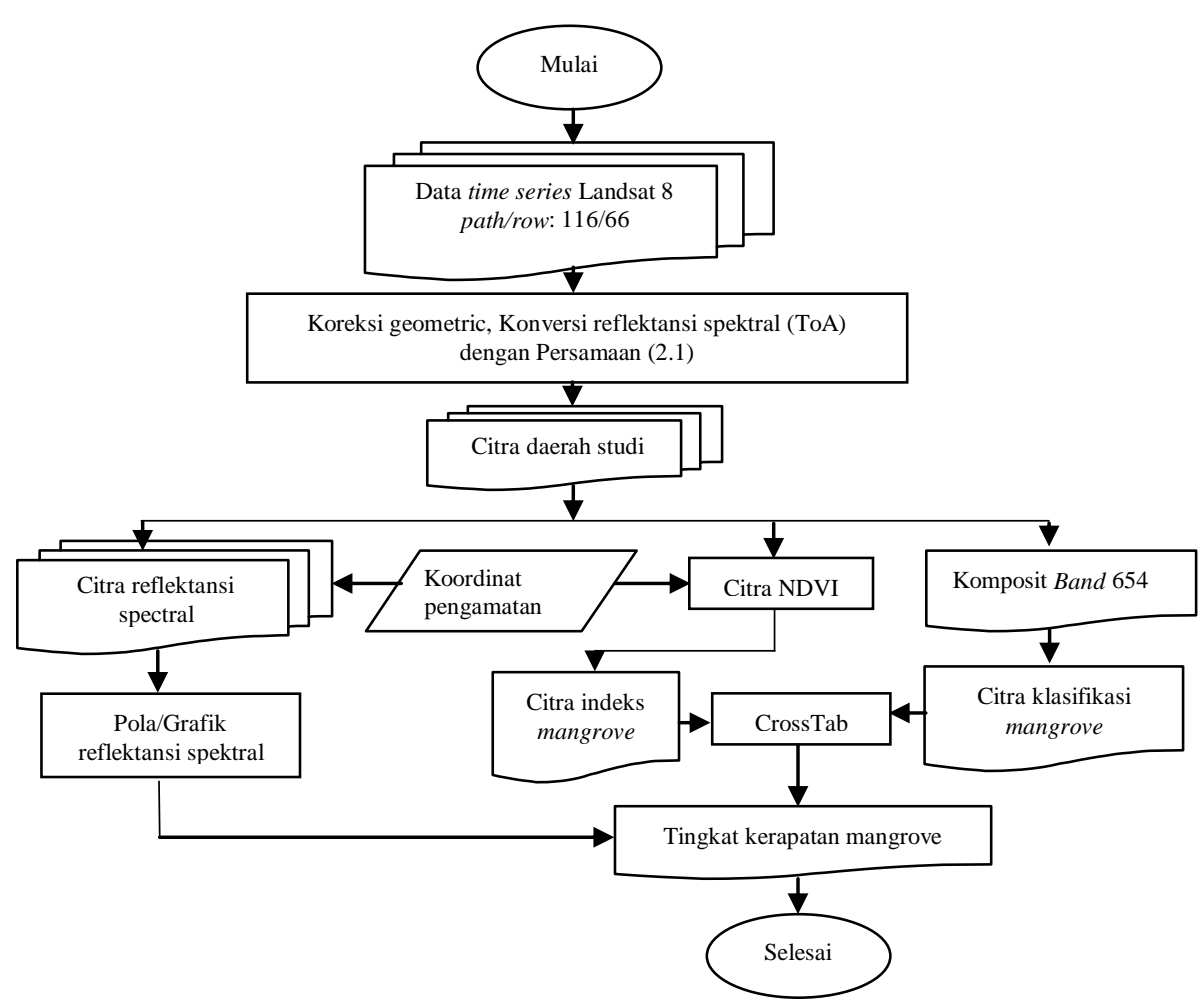

Gambar 3. Proses pengolahan data.

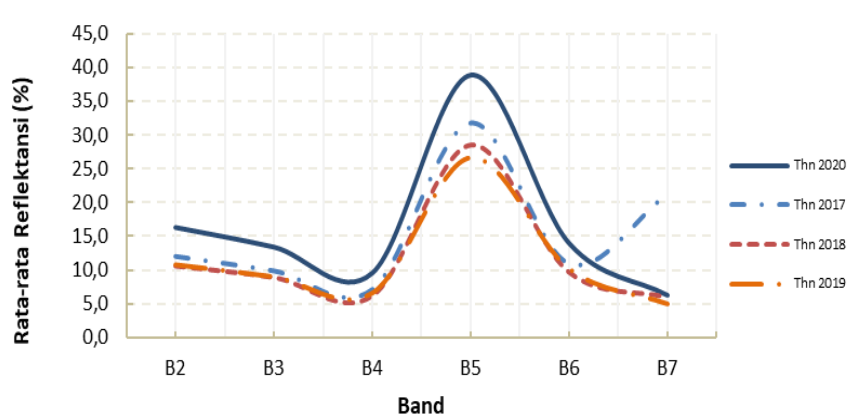

Gambar 4. Karakteristik nilai piksel rata-rata citra reflektansi spektral mangrove tahun 2017-2020.

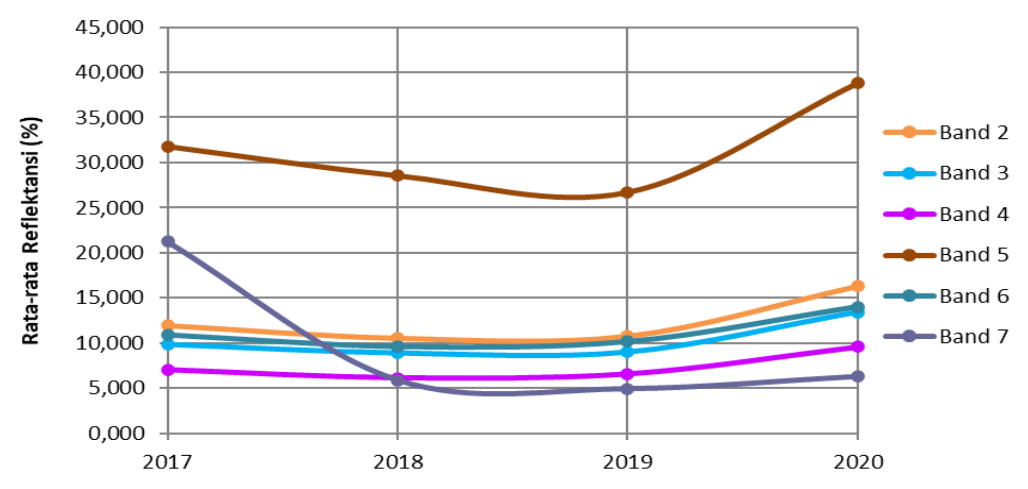

Gambar 5. rata-rata reflektansi spektral untuk band 2 sampai band 7 dari tahun 2017-2020.

Dari grafik pola reflektansi spektral pada Gambar 4 dan 5 dapat dilihat bahwa, nilai reflektansi tertinggi untuk panjang gelombang NIR (band 5) yaitu pada tahun 2020, yaitu sebesar 38,775 \% dan untuk nilai terkecil yaitu pada tahun 2019 sebesar 26,727 \%. Pada dasarnya panjang gelombang NIR dapat digunakan untuk melihat vegetasi yang tidak sehat (stress). 
4.2 Citra indeks vegetasi dan indeks mangrove

Model indeks vegetasi yang dianalisis pada penelitian ini adalah indeks vegetasi NDVI yang dihitung menggunakan Persamaan (2) seperti ditunjukkan pada Gambar 6.
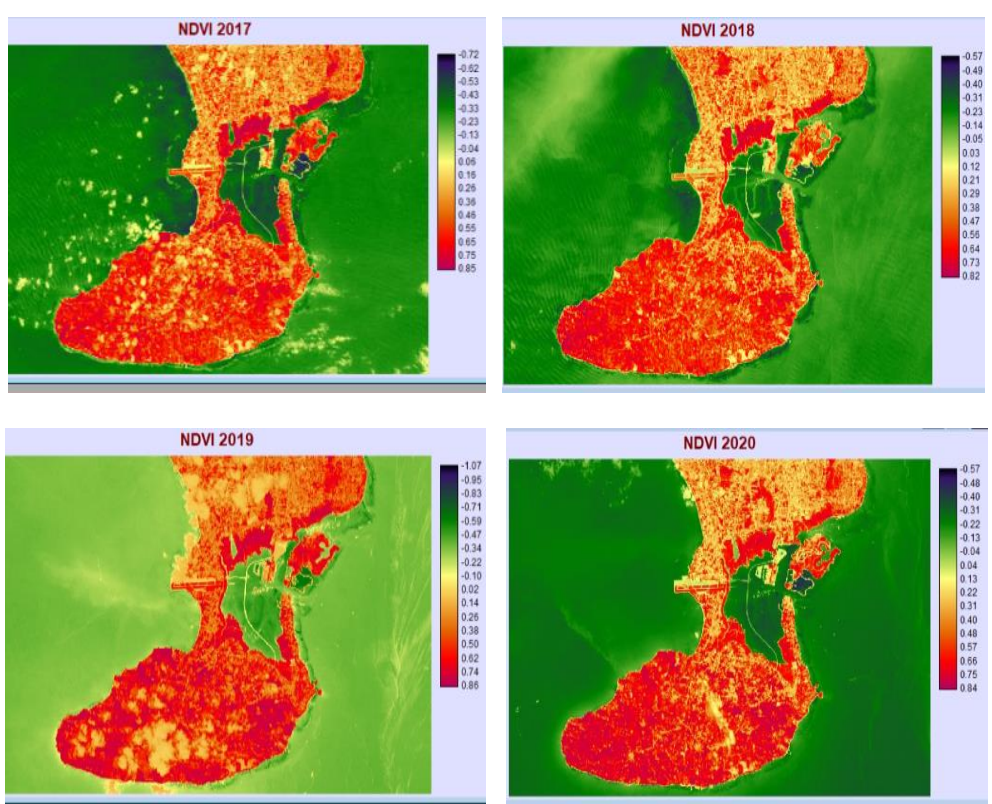

Gambar 6. Citra NDVI berbasis citra reflektansi spektral tahun 2017-2020.

Hasil pengukuran nilai indeks vegetasi NDVI berbasis reflektansi spektral pada 20 TP yang terindikasi sebagai mangrove disajikan pada Gambar 7.

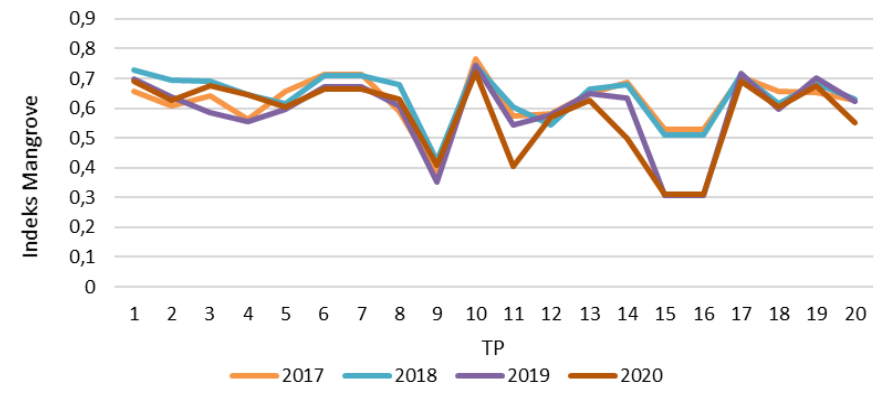

Gambar 7. Grafik Indeks Mangrove pada 20 TP tahun 2017-2020.

4.3 Citra sebaran mangrove hasil analisis crosstab

Klasifikasi kelas sebaran kerapatan mangrove ditentukan dengan analisis crosstab antara citra indeks mangrove dengan citra klasifikasi mangrove - nonmangrove. Citra hasil analisis proses crosstab disajikan pada Gambar 8.
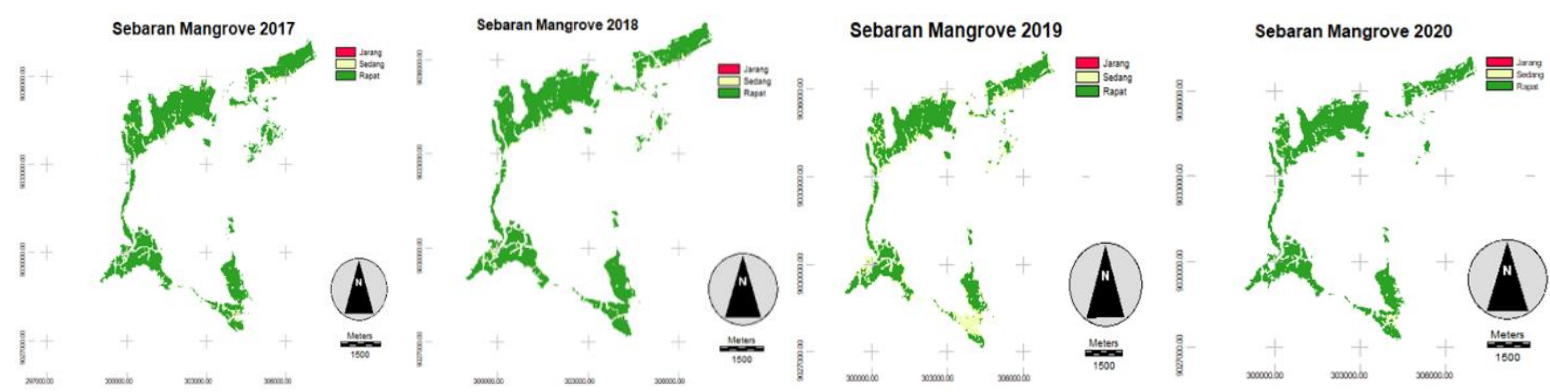

Gambar 8. Hasil analisis proses crosstab antara citra indeks mangrove dengan citra klasifikasi mangrove nonmangrove. 
Introduction of Spectral Reflectance Pattern in Benoa Bay as an Indicator ........

(Wiwik Kurniawati, dkk)

Hasil estimasi luas areal dan klasifikasi kelas sebaran vegetasi mangrove yang diperoleh melalui analisis crosstab disajikan pada Tabel 3.

Tabel 3. Estimasi luas areal dan kelas sebaran vegetasi mangrove.

\begin{tabular}{ccccc}
\hline \multirow{2}{*}{ Tahun } & \multicolumn{4}{c}{ Luas areal kelas sebaran vegetasi mangrove (ha) } \\
\cline { 2 - 5 } & Jarang & Sedang & Rapat & Luas Total \\
\hline 2017 & 0,09 & 85,77 & 923,94 & $1.009,80$ \\
2018 & 0,09 & 65,52 & 907,47 & 973,08 \\
2019 & 0,45 & 284,22 & 749,61 & $1.034,28$ \\
2020 & 0,09 & 35,91 & 816,39 & 852,39 \\
\hline
\end{tabular}

Perhitungan indeks vegetasi NDVI pada tahun 2017-2020 Gambar 7. menunjukkan bahwa, terdapat pengurangan luas areal mangrove Tabel 3. dari tahun 2017 hingga 2018 sebesar 36,72 ha. Pada tahun 2019 luas areal mangrove mengalami peningkatan yang cukup besar dari tahun 2018 yaitu sebesar 60,82 ha. Peningkatan luas areal mangrove ini terjadi akibat penanaman kembali sebanyak 100.000 bibit mangrove yang dilakukan Pelindo sebagai upaya pertanggungjawaban atas kematian mangrove yang terjadi akibat proyek reklamasi (https://www.mongabay.co.id). Pada tahun 2020, luas areal mangrove kembali mengalami pengurangan yang cukup drastis sebesar 181,51 ha dan luas areal yang tercatat masih ditumbuhi mangrove pada tahun 2020 hanya sebesar 852,39 ha. Hal ini mengindikasikan bahwasannya penanaman kembali terhadap mangrove tidak memulihkan atau mengembalikan keadaan mangrove yang telah mati. Disamping itu juga diduga terjadi akibat kegiatan reklamasi yang membawa banyak sedimen yang kemudian menutupi akar mangrove sehingga, menyebabkan mangrove mati.

Berdasarkan perubahan pola reflektansi yang didapatkan pada Gambar 4. dapat dilihat kaitannya dengan perubahan luas areal mangrove yang disajikan pada Tabel 3. Berdasarkan pola reflektansi spektral, panjang gelombang NIR (band 5) dapat dijadikan sebagai acuan telah terjadi pengurangan luas areal mangrove, dimana semakin kecil nilai reflektan pada band 5 menunjukkan pengurangan atau kerusakan luasan mangrove di tahun tersebut semakin besar. Dari Gambar 4. perubahan rata-rata nilai reflektansi untuk setiap band pada setiap tahunnya berkaitan erat dengan kondisi atau perubahan kerapatan vegetasi di tahun yang sama. Perubahan pola reflektansi untuk setiap band dari tahun 2017 mengalami penurunan dan kenaikan pada tahun 2020. Kaitannya dengan kerusakan atau perubahan luasan yang dialami mengindikasikan bahwasannya semakin kecil nilai reflektansi pada band di setiap tahunnya berbanding lurus dengan pengurangan atau kerusakan mangrove yang terjadi di tahun tersebut.

\section{Kesimpulan}

Perubahan pola reflektansi spektral mangrove di Teluk Benoa dari tahun 2017-2020 mengalami penurunan dan kenaikan untuk setiap bandnya. Perubahan dari tahun 2017 ke 2018 untuk puncak reflektansinya (band 5) mengalami penurunan sebesar 3,23\% dari 31,81\% pada tahun 2017 menjadi 28,58\% di tahun 2018. Dari tahun 2018 ke tahun 2019 pola yang dihasilkan dari puncak reflektansinya juga mengalami penurunan sebesar 1,85\% sehingga pada tahun 2019 menjadi 26,73\%. Akan tetapi pada tahun 2020 nilai puncak reflektansi dari band 5 mengalami kenaikan sebesar 12,045\% menjadi 38,775\% di tahun 2020. Perubahan pola reflektansi tahun 2017 ke 2018 mengakibatkan terjadinya perubahan kerapatan dan perubahan luas mangrove untuk kategori sedang dari 85,77 ha menjadi 65,52 ha, dan untuk kategori rapat berkurang sebesar 16,47 ha dari 923,94 ha di tahun 2017 menjadi 907,47 ha di tahun 2018. Pada tahun 2019 mengalami pengurangan luasan yang sangat drastis dari tahun 2018 untuk kategori rapat yaitu sebesar 157,86 ha sehingga menjadi 749,61 di tahun 2019, untuk kategori sedang bertambah dari tahun 2018 sebesar 218,7 ha menjadi 284,22 ha dan untuk kategori jarang bertambah dari tahun sebelumnya 0,9 ha menjadi 0,45 ha. Di tahun 2020 untuk kategori jarang luasan mangrove berkurang sebesar 0,36 ha dari tahun 2019 menjadi 0,9. Kategori sedang berkurang 248,32 ha menjadi 35,91 ha dan untuk kategori rapat mengalami kenaikan sebesar 66,78 ha dari tahun 2019 sehingga luas kategori rapat pada tahun 2020 menjadi 816,39 ha.

\section{Ucapan Terima Kasih}

Penulis menyampaikan terimakasih kepada dosen bidang minat Fisika Bumi, Prodi Fisika, FMIPA, UNUD yang telah memberikan saran serta masukan terkait penelitian ini. 


\section{Pustaka}

[1] A. Sofian, N. Harahab, dan Marsoedi, Kondisi dan Manfaat Langsung Ekosistem Hutan Mangrove Desa Penunggul Kecamatan Nguling Kabupaten Pasuruan, El-Hayyah Journal, vol.2, no.2, 2012, pp. 56-63.

[2] W. E. Suryadyana., I. D. M. Darmawan, dan I. K. A. Wirawan, Eksplorasi Ekosistem Mangrove Teluk Benoa dalam Karya Fotografi Ekspresi, 2018. Available from: http://repo.isi-dps.ac.id/3061/, diakses 10 Desember 2020.

[3] M. Iskandar, T. B. Sanjoto, dan Sutardji, Analisis Kerapatan Vegetasi Menggunakan Teknik Penginderaan Jauh Sebagai Basis Evaluasi Kerusakan Hutan di Taman Nasional Gunung Gede Pangrango, Jurnal unnes, vol. 1, no.1, 2012, pp. 94-101.

[4] E. Molidena dan A. R. As-syakur, Karekteristrik Pola Spektral Vegetasi Hutan Dan Tanaman Industri Bedasarkan Data Penginderaan Jauh, Prosiding Pertemuan Ilmiah Tahunan MAPIN XIX, Makasar, Juni 2012, pp. 1-5.

[5] M. Yuliara, Pemanfaatan Citra Landsat Untuk Studi Karakteristik Reflektan Mangrove Di Benoa, Buletin Fisika Universitas Udayana, vol. 13, no. 1, 2012, pp. 15-19.

[6] M. Yuliara, Studi Karakteristik Reflektan Spektral Cengkeh menggunakan Data Landsat 8 Di Kabupaten Buleleng Bali, Penelitian Mandiri, Universitas Udayana, Bali, 2015.

[7] A. Ridho, Pola Spektral Daun Mangrove Dengan Menggunakan Spektrofotometer Dan Citra Worldview-2 Di Perairan Pulau Pari, Skripsi, Departemen Ilmu dan Teknologi Kelautan, Fakultas Perikanan dan Ilmu Kelautan Institut Pertanian Bogor, 2015.

[8] USGS.gov. USA: Department of the interior, Available from: http://earthexplorer.usgs.gov/. [diakses 4 Desember 2020].

[9] S. Irawan, dan J. Sirait, Perubahan Kerapatan Vegetasi Menggunakan Citra Landsat 8 di Kota Batam Berbasis Web, Jurnal Kelautan, vol. 10, no. 2, 2017, pp. 174-184.

[10] Irwanto, Hutan Mangrove dan Manfaatnya, 2008. Available from: http://irwantoshut.com, diakses 13 Oktober 2020.

[11] E. K. Andana, Pengembangan Data Citra Satelit Landsat-8 Untuk Pemetaan Area Tanaman Hortikultura Dengan Berbagai Metode Algoritma Indeks Vegetasi, Prosiding Seminar Nasional Manajemen Teknologi XXII, Surabaya, 2015, pp. 1-10.

[12] K. Darmo, Analisa Perubahan Luas Tingkat Kerapatan Mangrove Taman Hutan Raya Ngurah Rai Bali dengan Menggunkan Citra Satelit Landsat 8, Buletin Fisika Universitas Udayana, vol. 19, no. 2, 2018, pp. 58-63.

[13] Departemen Kehutanan, Pedoman Inventarisasi dan Identifikasi Lahan Kritis Mangrove, Jakarta, 2005. 